Copyright (C) 2017 by Academic Publishing House Researcher

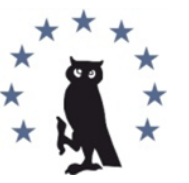

Published in the Russian Federation

European Researcher. Series A

Has been issued since 2010.

ISSN 2219-8229

E-ISSN 2224-0136

2017, 8(3): 212-223

DOI: $10.13187 /$ er.2017.3.212

www.erjournal.ru

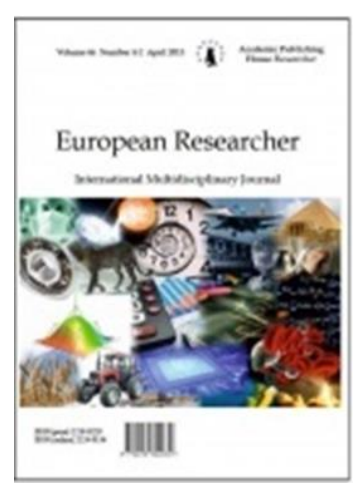

UDC 698

\title{
Cost and Time Optimalization on the Implementation of Building Construction Project
}

\author{
Yulius Teguh Prihanto a, *, Subandiyah Azis a , Tiong Iskandar a \\ a National Institute of Technology Malang, Indonesia
}

\begin{abstract}
The aims of the research are 1) to analyze the cost of work for Building A of Christian Center Samarinda project based on historical data by using simulation technique (Monte Carlo method), 2) to analyze the duration of Building A Christian Center Samarinda project based on historical data by using simulation technique (linear programming and simulation method). This research uses descriptive method. Descriptive method can be interpreted as a problem-solving procedure investigated by describing the state of the subject or object in the research, it can be people, institutions, communities and others at current time which are based on facts as the way they are. The results of this research are 1) the final cost of the construction project of Building A Christian Center Samarinda based on historical data by using simulation technique (Monte Carlo method) is IDR 23.257.368.872,85 with the addition of operating cost of IDR 129.408.041,65 from the Budget Plan for the implementation of IDR 22.726.159136,00, 2) the implementation time of construction project of Building A Christian Center Samarinda based on historical data by using simulation technique (linear programming and simulation method) is 115 days, or there is an accelerated of the duration as long as 35 days from the implementation time of 150-days calendar. Therefore, it obtains deviation value of IDR 11.480.048,43 per day.
\end{abstract}

Keywords: project, Monte Carlo, linear programming and simulation.

\section{Introduction}

Optimization problem is the most common problem encountered in all aspects of life. A special form of optimization problem is linear programming, this linear program is widely used in industry, transportation, commerce and so on, the operations research approach is a scientific method that specifically initiates this process by observing and formulating the problems and then building a scientific model (typically mathematical) who seek to abstract the essence of the real problem. One part of the linear program currently used and developed by people is the theory of network analysis (Folke et al, 2002). The network can be used to describe the interrelationships among the project elements or show all the activities contained within the project and the logic of its reliance on each other. In relation to this project issue, successful on-time implementation of a project is an important goal for both owners and contractors (Robert, 2004). Delays are a very

\footnotetext{
${ }^{*}$ Corresponding author

E-mail addresses: prihanto.teguh@gmail.com (Y.T. Prihanto)
} 
undesirable condition, because it will harm both parties, both in terms of time and cost (Hartley, Jones, 1997).

Scheduling is an important thing in a construction project. Scheduling compiles an estimate of the time period required to complete a project. Scheduling is used as a guideline to create cost planning, execute, control and make an evaluation of the implementation of the project (Eppen et al, 1998). Therefore, the preparation of the schedule should be made in such a way that it is close to the reality in the field. In preparing a construction project schedule, it must first determine the duration of completion of each activity undertaken on the project. After the duration of each activity is known, then the overall schedule can be compiled. The determination of the duration of an activity is something that can not exactly be calculated, because when an activity is ongoing, factors that affect it remain unknown, and it also cannot be exactly known how long an activity can be completed. In deter excavation the duration, it should consider the level of labor productivity, (Frida, 2010). This level should be known because the level of productivity of each labor is not the same, especially one area with others. In deter excavation the duration of an activity, it is necessary to know the highest and lowest levels of labor productivity or skill (Stark, Mayer, 1983). Unexpected events, such as natural conditions (weather), the delays and mistakes of material suppliers, traffic jams, engine breakdowns, sabotage, and so on are also something to consider even at relatively small probability levels.

The inefficient working time, errors in the implementation of an activity or lack of understanding of the work will affect the duration of the event (Gittell, Vidal, 1998). As a result of these matters, it results in the addition of time to repeat the work and or dismantle it. This will affect the overall duration of the project or the project will be experiencing delays. This delay will result in additional cost to accelerate or control the implementation of the project (Guivant, Nebot, 2001). If the duration of an activity is accelerated, it will require more resources to complete the work. The addition of resources can be materials, tools, methods or labors so that the addition of resources means additional costs. Additional costs, as a result of the addition of resources, should find the minimum additional cost to complete the work (Taha, 1997).

In accordance with the description above, the problems of the research are: 1) how much is the cost of Building A Christian Center Samarinda project based on historical data by using simulation techniques (Monte Carlo method)?, 2) how long is the duration of Building A Christian Center Samarinda project based on historical data by using simulations techniques (linear programming and simulation method)?

Recognizing the importance of the problems that have been formulated, the objectives in this research are: 1) to analyze the cost of Building A Christian Center Samarinda project based on historical data by using simulation techniques (Monte Carlo method), 2) to analyze the duration of Building A Christian Center Samarinda project based on historical data by using simulations techniques (linear programming and simulation method).

\section{Research Methods}

Identify applicable sponsor/s here.

This research uses descriptive method. Descriptive method can be interpreted as a problemsolving procedure investigated by describing the state of the subject or object in the research, it can be people, institutions, communities and others at current time which are based on facts as the way they are (Wahyu, 2008). There are some key features in descriptive methods, including:

a. Concentrate on the existing problems when the research is on-going or on the actual problems.

b. Describing the facts about the investigating problems as they should be, accompanied by a balanced rational interpretation.

c. The researcher job is not only providing an overview of the phenomena, but also explaining the relationship, testing the hypothesis, making predictions, and obtaining the meaning and implications of a problem. 


\section{Results and Discussion}

\subsection{Cost Simulation}

The first step in the calculation of cost simulation is to analyze the increase of unit price between project data and historical data. Based on historical data, it is obtained the following unit price for the excavation work:

In 2013, the cost of the excavation work unit is IDR $48.057,50 / \mathrm{m}^{3}$

In 2016, the cost of the excavation work unit is IDR $58.500,00 / \mathrm{m}^{3}$

The unit price of excavation work for ongoing project data (in 2017) is IDR $74.825,00 / \mathrm{m}^{3}$. Equation (1) was used in this data.

$$
\mathrm{TKH}=\frac{\mathrm{HS} 2017}{\mathrm{HS} 13 / 16}
$$

It obtains the increase of unit price for the excavation works against 2013 as follows.

$$
\text { TKH } 13=\frac{74.825}{48.057}=1.5570
$$

The same way obtains the increase of the unit price on 2016 as much as 1.2790 times. The explanation of the analysis calculation of the increase unit price is represented by a type of work only. Historical data about cost, volume and duration, for excavation work are given in Table 1.

Table 1. Historical Data of the Excavation Work

\begin{tabular}{|l|l|l|l|}
\hline Year & Cost (IDR) & Volume & Duration \\
\hline 2013 & 9.971 .931 & $207,50 \mathrm{~m}^{3}$ & 21 \\
\hline 2015 & 1.939 .525 & $25,88 \mathrm{~m}^{3}$ & 2 \\
\hline 2016 & 24.750 .235 & $422,91 \mathrm{~m}^{3}$ & 10 \\
\hline
\end{tabular}

From the historical data for the excavation work in the table above, then it calculates the cost of work in 2017 and the cost of its work unit as can be seen in Table 2.

Table 2. Calculation Results

\begin{tabular}{|l|l|l|l|l|}
\hline Year & Cost (IDR) & $\begin{array}{l}\text { Cost (IDR) Year } \\
2017\end{array}$ & Volume $\left(\mathrm{m}^{3}\right)$ & Unit Cost (IDR) \\
\hline 2013 & 9.971 .931 & 18.667 .454 & 207,50 & 89.963 \\
\hline 2015 & 1.939 .525 & 3.630 .790 & 25,88 & 140.293 \\
\hline 2016 & 24.750 .235 & 46.332 .439 & 422,91 & 109.556 \\
\hline
\end{tabular}

The cost of the work in 2017 is obtained by using the equation 3 multiplication between the cost of historical data and the rate of the price increase.

$$
\begin{aligned}
& \text { B } 2017=\text { B } 13 / 16 \times \text { TKH } \\
& \text { B } 2017=9.971 .931 \times 1.23 \\
& \text { B } 2017=\text { IDR } 12.265 .475, \text { OO }
\end{aligned}
$$

The cost per unit of work in Table 4.3, is then calculated by using equation (2).

$$
\mathrm{Bs}=\frac{\mathrm{B} 2017}{\text { Volume }} \quad \text { (2) } \mathrm{Bs}=\frac{12.265 .475}{207,50}=\text { IDR } 59.110
$$

The unit cost for each historical data is then determined the probability, they are (3):

$$
\begin{array}{ll}
\text { Prob } \mathrm{i}=\frac{B s . i}{\sum B S} \times 100 \% & \text { (3) } \\
& \text { Prob i }=\frac{89.963}{339.813} \times 100 \%=26,474 \%
\end{array}
$$


The calculation of probability above is used to determine the random number interval (it is obtained the random number interval from the calculation above, which is o to 15). The calculation of probability and the random number interval from the historical data of other excavation work are written in the Table 3.

Table 3. The Calculation of Probability and Random Number Intervals for Unit Costs

\begin{tabular}{|l|l|l|l|l|}
\hline $\begin{array}{l}\text { Historical } \\
\text { Data }\end{array}$ & Unit Cost (IDR) & Probability & \multicolumn{2}{|l|}{ Random Number } \\
\hline 1 & 89.963 & 26.474 & 0 & 15 \\
\hline 2 & 140.293 & 41.285 & 16 & 31 \\
\hline 3 & 109.556 & 32.240 & 32 & 48 \\
\hline Total & 339.813 & 100 & & \multicolumn{2}{|l|}{} \\
\hline
\end{tabular}

The calculation of cost simulation per unit volume for excavation work is given in Table 4 .

Table 4. Cost Simulation Per Unit Volume

\begin{tabular}{|l|l|l|l|l|l|}
\hline No & $\begin{array}{l}\text { Random } \\
\text { Number }\end{array}$ & Unit Cost & $\begin{array}{l}\text { Volume } \\
(\mathrm{m} 3)\end{array}$ & $\begin{array}{l}\text { Cumulative Unit } \\
\text { Cost }\end{array}$ & $\begin{array}{l}\text { Cumulative } \\
\text { Volume }\end{array}$ \\
\hline 1 & 87 & $140.293,00$ & 1 & $140.293,00$ & 1 \\
\hline 2 & 1 & $89.968,00$ & 1 & $230.261,00$ & 2 \\
\hline 3 & 5 & $89.968,00$ & 1 & $320.229,00$ & 3 \\
\hline 4 & 68 & $140.293,00$ & 1 & $460.522,00$ & 4 \\
\hline 5 & 89 & $140.293,00$ & 1 & $600.815,00$ & 5 \\
\hline 6 & 29 & $140.293,00$ & 1 & $741.108,00$ & 6 \\
\hline 7 & 36 & $140.293,00$ & 1 & $881.401,00$ & 7 \\
\hline 8 & 84 & $140.293,00$ & 1 & $1.021 .694,00$ & 8 \\
\hline 9 & 53 & $140.293,00$ & 1 & $1.161 .987,00$ & 9 \\
\hline 10 & 16 & $89.968,00$ & 1 & $1.251 .955,00$ & 10 \\
\hline 11 & 86 & $140.293,00$ & 1 & $1.392 .248,00$ & 11 \\
\hline 12 & 40 & $140.293,00$ & 1 & $1.532 .541,00$ & 12 \\
\hline 13 & 45 & $140.293,00$ & 1 & $1.672 .834,00$ & 13 \\
\hline 14 & 98 & $140.293,00$ & 1 & $1.813 .127,00$ & 14 \\
\hline 15 & 93 & $140.293,00$ & 1 & $1.953 .420,00$ & 15 \\
\hline 16 & 33 & $140.293,00$ & 1 & $2.093 .713,00$ & 16 \\
\hline 17 & 88 & $140.293,00$ & 1 & $2.234 .006,00$ & 17 \\
\hline 18 & 6 & $89.968,00$ & 1 & $2.323 .974,00$ & 18 \\
\hline 19 & 61 & $140.293,00$ & 1 & $2.464 .267,00$ & 19 \\
\hline 20 & 46 & $140.293,00$ & 1 & $2.604 .560,00$ & 20 \\
\hline 21 & 25 & $140.293,00$ & 1 & $2.744 .853,00$ & 21 \\
\hline 22 & 4 & $89.968,00$ & 1 & $2.834 .821,00$ & 22 \\
\hline 23 & 41 & $140.293,00$ & 1 & $2.975 .114,00$ & 23 \\
\hline 24 & 72 & $140.293,00$ & 1 & $3.115 .407,00$ & 24 \\
\hline 25 & 47 & $140.293,00$ & 1 & $3.255 .700,00$ & 25 \\
\hline & & & & & \\
\hline
\end{tabular}

The sum of the cumulative unit costs are divided by the sum of the cumulative volumes at the last random number, it obtains the cost per $\mathrm{m}^{3}$ of excavation work (simulation results). This calculation uses equation (4).

$$
\text { Bsim }=\frac{\text { Bs.Kom.25 }}{\text { Vol Kom,25 }}
$$

$$
\operatorname{Bsim}=\frac{3.255 .700}{25}=130.228,00 / \mathrm{m}^{3}
$$


Project Data of 2017, the Building A Christian Center Samarinda project Phase 1, for the excavation work, has $48.057 \mathrm{~m}^{3}$ volume, so the cost of the work in the crash condition is:

$$
\begin{aligned}
& B=130.228 \times 48,057 \\
& B=6.258 .366 .996
\end{aligned}
$$

\subsection{The Simulation of Work Volume per Day}

Historical data for the excavation work that contain data on the work volume and work duration, as in Table 5.

Table 5. Historical Data for the Excavation Work

\begin{tabular}{|l|l|l|l|l|}
\hline Year & Cost (IDR) & Volume $\left(\mathrm{m}^{3}\right)$ & Duration & $\begin{array}{l}\text { Volume/Day } \\
\left(\mathrm{m}^{3}\right)\end{array}$ \\
\hline 2013 & 9.971 .931 & 207,50 & 21 & 9.880 \\
\hline 2015 & 1.939 .525 & 25,88 & 2 & 12,94 \\
\hline 2016 & 24.750 .235 & 422,91 & 10 & 42.291 \\
\hline
\end{tabular}

Volume Calculation per day in the table above uses equation (5).

$\mathrm{Vs}=\frac{\mathrm{Vp}}{\text { Duration }}$

$$
\mathrm{Vs}=\frac{207,50}{21}=9.880 \mathrm{~m}^{3}
$$

The calculation of its probability with the following equation is conducted after obtaining the volume per day for each historical data,

$$
\begin{gathered}
\text { Proba } i=\frac{V s . i}{\sum V s} \times 100 \% \\
\text { Proba } i=\frac{12,94}{65.111} \times 100 \%=0,1987 \%(\text { rounded to } 19 \%)
\end{gathered}
$$

The probability calculation is used to determine the random number interval (the calculation above is obtained by random number interval, $o$ to 15 ). The calculation and random number interval for volume/day and others are written in Table 6.

Table 6. The calculation of probability and random number interval for volume/day

\begin{tabular}{|l|l|l|l|}
\hline Historical Data & Volume/Day $\left(\mathrm{m}^{3}\right)$ & Probability & Number Random \\
\hline 1 & 9.880 & 16 & 0 \\
\hline 2 & 12,94 & 38 & 16 \\
\hline 3 & 42.291 & 46 & 54 \\
\hline TOTAL & 65.111 & & \\
\hline
\end{tabular}

The calculation of simulation cost per volume unit is given in Table 7.

Table 7. Simulations of Work Volume Per Day of the Excavation Work

\begin{tabular}{|l|l|l|l|l|l|}
\hline No & $\begin{array}{l}\text { Random } \\
\text { Number }\end{array}$ & $\begin{array}{l}\text { Volume / Day } \\
(\mathrm{m} 3)\end{array}$ & Day & $\begin{array}{l}\text { Cumulative } \\
\text { Volume/Day (m3) }\end{array}$ & Cumulative Day \\
\hline 1 & 87 & 42.291 & 1 & 42.291 & 1 \\
\hline 2 & 1 & 9.88 & 1 & 52.171 & 2 \\
\hline 3 & 5 & 9.88 & 1 & 62.051 & 3 \\
\hline 4 & 68 & 12.94 & 1 & 74.991 & 4 \\
\hline 5 & 89 & 42.291 & 1 & 117.282 & 5 \\
\hline
\end{tabular}




\begin{tabular}{|l|l|l|l|l|l|}
\hline 6 & 29 & 9.88 & 1 & 127.162 & 6 \\
\hline 7 & 36 & 9.88 & 1 & 137.042 & 7 \\
\hline 8 & 84 & 42.291 & 1 & 179.333 & 8 \\
\hline 9 & 53 & 12.94 & 1 & 192.273 & 9 \\
\hline 10 & 16 & 9.88 & 1 & 202.153 & 10 \\
\hline 11 & 86 & 42.291 & 1 & 244.444 & 11 \\
\hline 12 & 40 & 12.94 & 1 & 257.384 & 12 \\
\hline 13 & 45 & 12.94 & 1 & 270.324 & 13 \\
\hline 14 & 98 & 42.291 & 1 & 312.615 & 14 \\
\hline 15 & 93 & 42.291 & 1 & 354.906 & 15 \\
\hline 16 & 33 & 9.88 & 1 & 364.786 & 16 \\
\hline 17 & 88 & 42.291 & 1 & 407.077 & 17 \\
\hline 18 & 6 & 12.94 & 1 & 420.017 & 18 \\
\hline 19 & 61 & 9.88 & 1 & 429.897 & 19 \\
\hline 20 & 46 & 12.94 & 1 & 442.837 & 20 \\
\hline 21 & 25 & 9.88 & 1 & 452.717 & 21 \\
\hline 22 & 4 & 12.94 & 1 & 465.657 & 22 \\
\hline 23 & 41 & 9.88 & 1 & 475.537 & 23 \\
\hline 24 & 72 & 42.291 & 1 & 517.828 & 24 \\
\hline 25 & 47 & 9.88 & 1 & 527.708 & 25 \\
\hline
\end{tabular}

The result of simulation of cumulative volume/day of last random number is divided by number of days with the number of cumulative days at last random number (6)

V sim $=\frac{\text { Vs.Kom. } .25}{\text { DKom.25 }}$

(6)

$$
\text { Vsim }=\frac{527.708}{25}=21.108 \mathrm{~m}^{3} / \text { day }
$$

Data project in 2017, Construction Project of Building A Christian Center Samarinda Phase 1, for the excavation work, has $819.07 \mathrm{~m}^{3}$ volume (so that the duration of the work in crash conditions is obtained by:

$$
\mathrm{V} \operatorname{sim}=\frac{819,07}{21.108}=38.803 \text { days }(\text { rounded to } 39 \text { days })
$$

\subsection{The Calculation of Additional Costs and Accelerated Duration}

Additional costs are the costs incurred when the work is speeded up to the speed limitation of the permitted duration. The additional costs are obtained from the subtractions between the cost of the crash conditions and the costs under normal conditions. The accelerated duration is obtained from the subtractions of costs between the crash condition and costs under normal conditions. Additional columns of cost and accelerated duration on the number value are written in the parentheses. It shows that the value is negative. Additional costs in the table above are negative; it means that the work cost under normal conditions has a higher/expensive value compared to the crash conditions. It can happen because of differences in the use of technology, implementation, the amount of labor, or work equipment. Duration accelerated is negative; it indicates that the duration of a work under normal condition is shorter than the duration under Crash condition. It means that the level of productivity in the normal condition is higher, which can be caused by differences in the use of technology, implementation, the amount of labor, or work equipment. Differences in the level of productivity of excavation work are due to differences in the use of heavy equipment. The heavy equipment used in the normal condition is manual (hoe), while in the crash condition is excavator. Additional costs and accelerated duration for each type of work are then used to determine the additional cost per day; additional cost is divided by the amount of accelerated duration (Wysocki et al, 1995). Additional costs per day will be optimized in order to obtain additional minimum cost with the accelerated duration. Additional cost and accelerated duration for each type of job are then used to determine the additional cost per day; additional cost that is divided by the number of duration that can be accelerated. Additional costs per day will be optimized in order to obtain minimum additional cost with the accelerated duration. 


\subsection{Linear Programming}

The aim of the use of linear programming is to look for the optimum solution (minimum) of the additional cost if the duration of the activity is accelerated. The target function is:

Minimum Z $=\mathrm{UaTa}+\mathrm{UbTb}+\ldots+\mathrm{UnTn}$

The value of Ua, Ub,.., Un ; additional cost per duration for each of the accelerated work.

$\mathrm{Ta}, \mathrm{Tb}, \ldots ., \mathrm{Tn}$ is a type of activity whose duration can be accelerated.

Additional cost/day for mobilization work (T1, activity number 1) from table 4.9 is IDR 53.926.110,00 / day, so Ua, Ta for such activity is: 53.926.110 T1

Type of work and the amount of additional cost / day for all work that can be accelerated from table 4.9, then can be determined its target function, as follow:

Minimum,

$\mathrm{Z}=53.926 .110 \mathrm{~T} 1+10.498 .635 \mathrm{~T} 6+541.671 \mathrm{~T} 16+1.628 .185 \mathrm{~T} 19+1.038 .943 \mathrm{~T} 24+29.984$ $\mathrm{T} 25+6.014 .5 \mathrm{OO} \mathrm{T} 28+29.984 \mathrm{~T} 29+316.122 \mathrm{~T} 30$

The data of the accelerated of the duration for each job in Table 4.1 becomes the constraint/limitation to minimize the objective function. The accelerated duration of Mobilization and Demobilization activities (activity number 1, T1) should not be more than 24 days.

T1 $\leq 24$ Limitations for the amount of maximum accelerated duration of another work are:

$\mathrm{T} 6 \leq 3 \mathrm{~T} 16 \leq 5 \mathrm{~T} 19 \leq 3 \mathrm{~T} 24 \leq 5$

$\mathrm{T} 25 \leq 5 \mathrm{~T} 28 \leq 1 \mathrm{~T} 29 \leq 2 \mathrm{~T} 30 \leq 1$

The interdependence relationship between the activities becomes the limitation to minimize the objectives function of 4.1 above. The limitation/constraint of this interdependence relationship uses the equation (7).

$\mathrm{Xb}-\mathrm{Xa}+\mathrm{Ta} \geq \mathrm{Da}$

$\mathrm{Xa}$ is the Early Start Date (ESD) of activity A (the preceding activity)

$\mathrm{Xb}$ is the Early Start Date (ESD) of activity A (the following activity)

$\mathrm{Da}$ is the duration of activity A (the preceding activity)

Ta is the amount of duration of activity A that can be accelerated

Activity No. 3 (demolition of old buildings) depends on the activity number 2, with the type of interdependency Start to Start and Lead Time for 18 days. The limitation for the interdependence relationship of activity number 2 and number 3 are:

$\mathrm{X} 2-\mathrm{X}_{3} \geq 18$

The relationship between activities with the Finish to Start type, such as activity number 14 (Soil Compaction Activity) depends on activity number 13, duration of activity number 13 is 7 days and 5 days of Lead time. Limitations for Finish to Start types, for activities number 13 and 16 are

$$
\mathrm{X} 14-\mathrm{X} 13 \geq 9
$$

Interdependence relationship for accelerated activities, such as Pile Caps (activity 41) depends on activity number 21; the Start to Start type, with the Lead time of 2 days are:

$\mathrm{X} 41-\mathrm{X} 21+\mathrm{T} 21 \geq 2$

The interdependence relationship for other activities are:

$$
\begin{array}{lll}
\mathrm{X} 6-\mathrm{X} 2 \geq 19 & \mathrm{X}_{3}-\mathrm{X} 2 \geq 18 & \mathrm{X} 9-\mathrm{X}_{5} \geq 1 \\
\mathrm{X} 10-\mathrm{X}_{5} \geq 1 & \mathrm{X} 11-\mathrm{X} 2 \geq 5 & \mathrm{X} 13-\mathrm{X} 6 \geq 9
\end{array}
$$




\begin{tabular}{|c|c|}
\hline $\mathrm{X} 14-\mathrm{X} 13 \geq 1$ & $\mathrm{X} 15-\mathrm{X} 3 \geq 12$ \\
\hline $\mathrm{X} 17-\mathrm{X} 33 \geq 1$ & $\mathrm{X} 18-\mathrm{X} 17 \geq 1$ \\
\hline $\mathrm{X} 20-\mathrm{X} 17 \geq 3$ & $\mathrm{X} 21-\mathrm{X} 18 \geq 1$ \\
\hline $\mathrm{X} 23-\mathrm{X} 17 \geq 2$ & $\mathrm{X} 24-\mathrm{X} 17 \geq 15$ \\
\hline $\mathrm{X} 28-\mathrm{X} 2 \geq 1$ & $\mathrm{X} 29-\mathrm{X} 2 \geq 1$ \\
\hline $\mathrm{X}_{32}-\mathrm{X} 28 \geq 1$ & $X_{33}-X_{32} \geq 2$ \\
\hline $\mathrm{X}_{3} 6-\mathrm{X}_{3} 8 \geq 1$ & $\mathrm{X}_{37}-\mathrm{X} 21+\mathrm{T} 21 \geq 2$ \\
\hline$X_{40}-X_{42} \geq 1$ & $\mathrm{X} 41-\mathrm{X} 21+\mathrm{T} 21 \geq 1$ \\
\hline$X 48-X_{50} \geq 1$ & $\mathrm{X} 49-\mathrm{X} 21+\mathrm{T} 21 \geq 2$ \\
\hline$X_{52}-X_{54} \geq 1$ & $\mathrm{X} 53-\mathrm{X} 21+\mathrm{T} 21 \geq 2$ \\
\hline $\mathrm{X}_{5} 6-\mathrm{X}_{5} 8 \geq 1$ & $\mathrm{X}_{57}-\mathrm{X} 21+\mathrm{T} 21 \geq 2$ \\
\hline$X 60-X 62 \geq 3$ & $\mathrm{X} 61-\mathrm{X} 21+\mathrm{T} 21 \geq 3$ \\
\hline$X 65-X 67 \geq 2$ & $\mathrm{X} 66-\mathrm{X}_{35}+\mathrm{T}_{35} \geq 4$ \\
\hline$X 69-X 71 \geq 3$ & $\mathrm{X}_{70}-\mathrm{X}_{39}+\mathrm{T}_{39} \geq 4$ \\
\hline$X_{73}-X_{75} \geq 3$ & $\mathrm{X}_{74}-\mathrm{X}_{39}+\mathrm{T}_{39} \geq 2$ \\
\hline$X_{77}-X_{79} \geq 3$ & $\mathrm{X}_{78}-\mathrm{X} 43+\mathrm{T} 43 \geq 3$ \\
\hline$X 81-X 83 \geq 2$ & $\mathrm{X} 82-\mathrm{X} 47+\mathrm{T} 47 \geq 3$ \\
\hline$X 85-X 87 \geq 3$ & $\mathrm{X} 86-\mathrm{X} 47+\mathrm{T} 47 \geq 3$ \\
\hline$X 89-X 91 \geq 3$ & $\mathrm{X}_{90}-\mathrm{X}_{51}+\mathrm{T}_{51} \geq 2$ \\
\hline$X 93-X 95 \geq 2$ & $\mathrm{X}_{94}-\mathrm{X}_{51}+\mathrm{T}_{51} \geq 2$ \\
\hline X97 - X99 $\geq 2$ & $\mathrm{X}_{98}-\mathrm{X}_{59}+\mathrm{T}_{59} \geq 2$ \\
\hline
\end{tabular}

$$
\begin{aligned}
& \mathrm{X} 16-\mathrm{X} 15 \geq 15 \\
& \mathrm{X} 19-\mathrm{X} 17 \geq 2 \\
& \mathrm{X} 22-\mathrm{X} 19 \geq 4 \\
& \mathrm{X} 25-\mathrm{X} 23 \geq 17 \\
& \mathrm{X} 31-\mathrm{X} 30 \geq 1 \\
& \mathrm{X} 34-\mathrm{X} 28 \geq 2 \\
& \mathrm{X} 38-\mathrm{X} 37+\mathrm{T} 37 \geq 1 \\
& \mathrm{X} 42-\mathrm{X} 41+\mathrm{T} 41 \geq 2 \\
& \mathrm{X} 50-\mathrm{X} 49+\mathrm{T} 49 \geq 3 \\
& \mathrm{X} 54-\mathrm{X} 53+\mathrm{T} 53 \geq 3 \\
& \mathrm{X} 58-\mathrm{X} 57+\mathrm{T} 57 \geq 3 \\
& \mathrm{X} 62-\mathrm{X} 61+\mathrm{T} 61 \geq 4 \\
& \mathrm{X} 67-\mathrm{X} 66+\mathrm{T} 66 \geq 3 \\
& \mathrm{X} 71-\mathrm{X} 70+\mathrm{T} 70 \geq 4 \\
& \mathrm{X} 75-\mathrm{X} 74+\mathrm{T} 74 \geq 2 \\
& \mathrm{X} 79-\mathrm{X} 78+\mathrm{T} 78 \geq 2 \\
& \mathrm{X} 83-\mathrm{X} 82+\mathrm{T} 82 \geq 2 \\
& \mathrm{X} 87-\mathrm{X} 86+\mathrm{T} 86 \geq 2 \\
& \mathrm{X} 91-\mathrm{X} 90+\mathrm{T} 90 \geq 3 \\
& \mathrm{X} 95-\mathrm{X} 94+\mathrm{T} 94 \geq 3 \\
& \mathrm{X} 99-\mathrm{X} 98+\mathrm{T} 98 \geq 3
\end{aligned}
$$

X10o is the Early Start Date (ESD) from the end or the finish of the project. Under the normal conditions $\mathrm{X} 100$ equals 150 days, then if the project will be accelerated within 10 days, the limitation is:

$$
\mathrm{X} 100 \leq 150-10
$$

$\mathrm{X} 100 \leq 140$

The problem formulation with the objective function in equation 4.1 and the limitation / constraints in equation will then be optimized to minimize the objective function by using Quantitative System-Linear Programming.

\subsection{Calculation Result of Linear Programming}

Calculation Result of Software Quantitative System-Linear Programming, with the objective goals and limitations/constraints results the additional minimum cost for each accelerated duration, which can be seen in Table 8.

Table 8. Additional Cost Per Accelerated Duration

\begin{tabular}{|l|l|l|l|l|l|l|}
\hline $\begin{array}{l}\text { Accelerated } \\
\text { Duration } \\
\text { (Days) }\end{array}$ & $\begin{array}{l}\text { ESD } \\
100^{*}\end{array}$ & $\begin{array}{l}\text { Additional } \\
\text { Cost (IDR) (Z) }\end{array}$ & No & $\begin{array}{l}\text { Acceleration } \\
\text { Name of } \\
\text { Activity }\end{array}$ & Type & $\begin{array}{l}\text { Duration } \\
\text { (Day) }\end{array}$ \\
\hline 5 & 150 & O & & & & \\
\hline 5 & 145 & $18,525,000$ & 28 & $\begin{array}{l}\text { Procurement of pile size 40 Cm } \\
\text { X 40 Cm L.6 m }{ }^{1} \text { (347 dots) }\end{array}$ & 5 \\
\hline 10 & 140 & $36,074,160$ & 35 & Concrete & Pile Caps & 1 \\
\hline 15 & 135 & $8,125,065$ & 35 & Spawning & Pile Caps & 2 \\
\hline 20 & 130 & $8,140,925$ & 35 & Formwork & Pile Caps & 1 \\
\hline 30 & 125 & $15,584,150$ & 96 & Concrete & $\begin{array}{l}\text { Ground Floor } \\
\text { Plate }\end{array}$ & 5 \\
\hline 35 & 120 & $6,014,500$ & 96 & Spawning & $\begin{array}{l}\text { Ground Floor } \\
\text { Plate }\end{array}$ & 5 \\
\hline
\end{tabular}

Description: * EDS10o is the Early Start Date of the end of the activity, or the completion of the project 
From the results of Table 8, the implementation costs of the project can be calculated when it is accelerated; the project value in normal conditions plus the accelerated cost.

$Z^{\prime}=22,726,159,136+Z$ the result of this calculation can be seen in Table 9.

Table 9. Implementation Costs of the Project If the Duration is Accelerated

\begin{tabular}{|l|l|l|}
\hline Day & Additional Costs (IDR) $(Z)$ & Implementation Cost of The Project (IDR) (Z) \\
\hline 115 & $3,161,220$ & $22,821,784,156.00$ \\
\hline 120 & $6,014,500$ & $22,818,622,936.00$ \\
\hline 125 & $15,584,150$ & $22,812,608,436.00$ \\
\hline 130 & $8,140,925$ & $22,797,024,286.00$ \\
\hline 135 & $8,125,065$ & $22,788,883,361.00$ \\
\hline 140 & $36,074,160$ & $22,780,758,296.00$ \\
\hline 145 & $18,525,000$ & $22,744,684,136.00$ \\
\hline 150 & 0 & $22,726,159,136.00$ \\
\hline
\end{tabular}

The table is then form in a line chart of project implementation cost when it is accelerated, as in Figure 1.

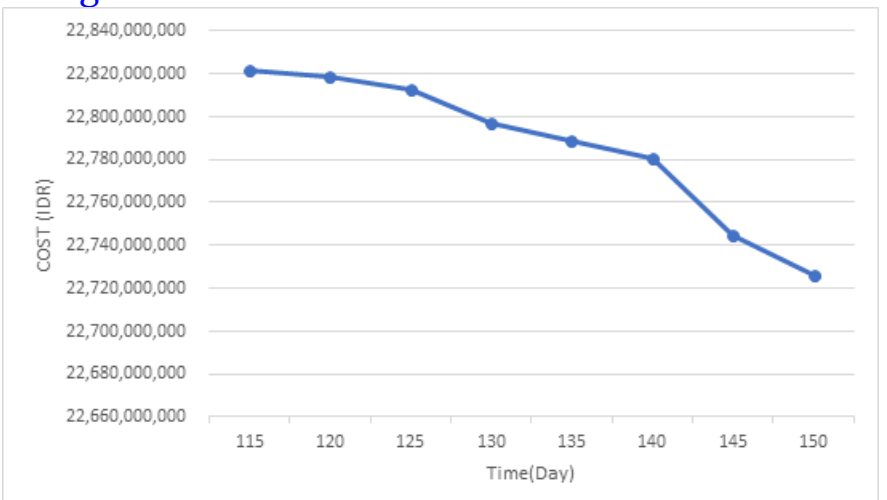

Fig. 1. Implementation Costs of the Project Due to the Accelerated Duration

The value of services and risks in Building A Christian Center Samarinda project is $5 \%$ of the project value (normal condition), or equal to IDR 1,136,307,956.80. The value is considered to be consisting of 50 percent operational costs and 50 percent profit. Furthermore, operational cost can be determined per day; operational cost is divided by the total of project duration (normal condition).

$$
\text { Operational Cost } / \text { day }=\frac{0,50 \times 1,136,307,956.80}{150 \text { days }}=\text { IDR 3,787,693.19 }
$$

After having operational cost per day, then the operational cost on certain days can be calculated, as shown in Table 10. 
Table 1o. Operational Costs of the Project

\begin{tabular}{|l|l|}
\hline Day & Operational Cost (IDR) \\
\hline 115 & $435,584,716.85$ \\
\hline 120 & $454,523,182.80$ \\
\hline 125 & $473,461,648.75$ \\
\hline 130 & $492,400,114.70$ \\
\hline 135 & $511,338,580.65$ \\
\hline 140 & $530,277,046.60$ \\
\hline 145 & $549,215,512.55$ \\
\hline 150 & $568,153,978.50$ \\
\hline
\end{tabular}

Table of operational costs above are then turned to a line chart, as in Figure 2.

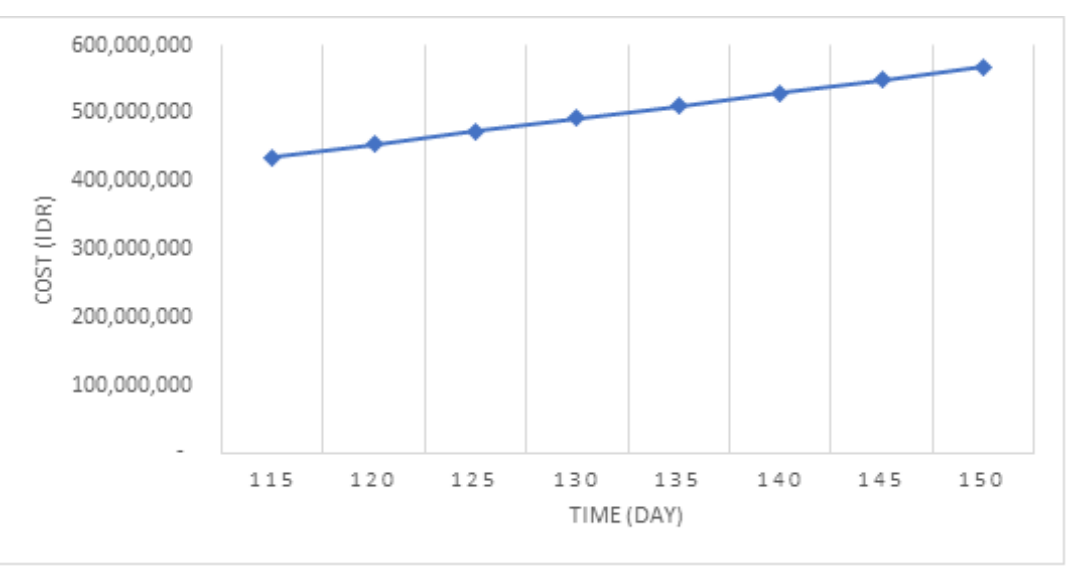

Fig. 2. Implementation Costs of the Project Due to the Accelerated Duration

By using the data in the table of implementation costs and operational costs of the project, then the final cost of the project can be calculated, it is the cost of the project implementation plus operational costs. The calculation of the final cost of the project is written in Table 11.

Table 11. Final Costs of the Project

\begin{tabular}{|l|l|l|l|}
\hline Day & $\begin{array}{l}\text { Implementation Costs of the } \\
\text { Project (IDR) (Z') }\end{array}$ & Operational Costs (IDR) & $\begin{array}{l}\text { Final Costs of the Project } \\
\text { (IDR) }\end{array}$ \\
\hline 115 & $22,821,784,156.00$ & $435,584,716.85$ & $23,257,368,872.85$ \\
\hline 120 & $22,818,622,936.00$ & $454,523,182.80$ & $23,273,146,118.80$ \\
\hline 125 & $22,812,608,436.00$ & $473,461,648.75$ & $23,286,070,084.75$ \\
\hline 130 & $22,797,024,286.00$ & $492,400,114.70$ & $23,289,424,400.70$ \\
\hline 135 & $22,788,883,361.00$ & $511,338,580.65$ & $23,300,221,941.65$ \\
\hline 140 & $22,780,758,296.00$ & $530,277,046.60$ & $23,311,035,342.60$ \\
\hline 145 & $22,744,684,136.00$ & $549,215,512.55$ & $23,293,899,648,55$ \\
\hline 150 & $22,726,159,136.00$ & $568,153,978.50$ & $23,294,313,114.50$ \\
\hline
\end{tabular}

The calculation results are shown in the graphical form of Figure 3. 


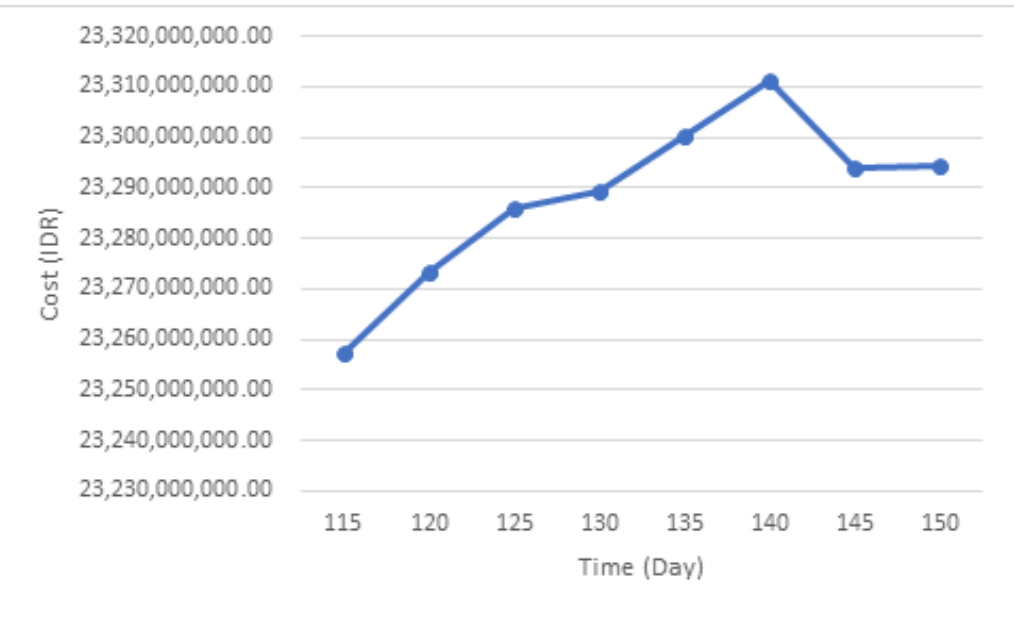

Fig. 3. Final Cost of the Project

Based on the calculation result, it is obtained the minimum cost of the final project is IDR 23.257.368.872,00 of the accelerated duration for 35 days, so that the project is completed on the 115th day. The results above also mean that if the project is completed within 130 days, will provide the difference between the additional costs with maximum operational cost savings. The calculation of the difference between the additional costs and the operational costs, for each accelerated of duration, is given in Table 12.

Table 12. Value of Difference between Additional Cost and Operational Cost

\begin{tabular}{|l|l|l|l|l|}
\hline $\begin{array}{l}\text { Total } \\
\text { Duration } \\
\text { of Project }\end{array}$ & $\begin{array}{l}\text { Additional Cost } \\
\text { (IDR) }\end{array}$ & $\begin{array}{l}\text { Accelerated } \\
\text { Duration }\end{array}$ & $\begin{array}{l}\text { Operational Cost } \\
\text { Savings }\end{array}$ & $\begin{array}{l}\text { Difference of Cost } \\
\text { (IDR) }\end{array}$ \\
\hline 115 & $3,161,220.00$ & 35 & $132,569,261.00$ & $129,408,041.65$ \\
\hline 120 & $6,014,500.00$ & 30 & $113,630,795.70$ & $107,616,295.70$ \\
\hline 125 & $15,584,150.00$ & 25 & $94,692,329.75$ & $79,108,179.75$ \\
\hline 130 & $8,140,925.00$ & 20 & $75,753,863.80$ & $67,612,938.80$ \\
\hline 135 & $8,125,065.00$ & 15 & $56,815,397.85$ & $48,690,332.85$ \\
\hline 140 & $36,074,160.00$ & 10 & $37,876,931.90$ & $1,802,771.90$ \\
\hline 145 & $18,525,000.00$ & 5 & $18,938,465.95$ & $413,465.95$ \\
\hline 150 & 0 & 0 & - & 0 \\
\hline
\end{tabular}

Description: *Maximum value of the difference between the additional cost and the cost savings.

Operational cost is an additional cost if the project is completed within 115 days it is IDR 3.161.220,00. The reduced operational cost is the daily operational cost multiplied by the amount of accelerated duration (35 days):

$=$ Rp. 3.787.693,19 x 35 days

$=$ Rp. 135.569.261,65

The difference, between additional costs and operational costs if the project is completed within 115 days, is:

$=\operatorname{Rp} 132,569,261.65-3,161,220.00$

$=\operatorname{Rp} 129,408,041.65$

\section{Conclusion}

Research on the Optimization of the Implementation Costs on Building Construction Project by using historical data of the similar projects which are still within the scope of the Christian Center Samarinda Building project, obtains the following conclusions: 
The final cost of the construction project of Building A Christian Center Samarinda based on historical data by using simulation technique (Monte Carlo method) is IDR 23,257,368,872.85 with the addition of operational cost of IDR 129,408,041.65 from the Budget Plan of the implementation cost of IDR 22.726.159.136,-- The implementation time of Building A Christian Center Samarinda project based on the historical data by using simulation technique (linear programming and simulation method) is $\mathbf{1 1 5}$ days, or there is an accelerated duration of 35 days from the time of the 150-day calendar. Therefore, it results the value of deviation of Rp. 11.480.048.43 / day.

\section{References}

Eppen et al., 1998 - Eppen, G.D., Gould, F.J., Schmid, C.P., Moore, J.H., Weatherford, L.R., (1998). Introductory Management Science, Decision Modeling with Spreadsheets, 1 (5), Chapter 11, Monte Carlo Simulation, Prentice Hall International, Inc., New Jersey.

Folke et al., 2002 - Folke, C., Carpenter, S., Elmqvist, T., Gunderson, L., Holling, C. S., Walker, B. (2002). Resilience and sustainable development: building adaptive capacity in a world of transformations. AMBIO: A journal of the human environment, 31(5), 437-440.

Frida, 2010 - Frida, K. (2010). Optimasi Pendanaan Proyek Dengan Teknik Pemrograman Linier (Studi Kasus: Proyek proyek dengan kontrak Unit Price), Tesis Universitas Diponegoro Semarang.

Gittell, Vidal, 1998 - Gittell, R., Vidal, A. (1998). Community organizing: Building social capital as a development strategy. Sage publications.

Guivant, Nebot, 2001 - Guivant, J. E., Nebot, E. M. (2001). Optimization of the simultaneous localization and map-building algorithm for real-time implementation. IEEE transactions on robotics and automation, 17(3), 242-257.

Hartley, Jones, 1997 - Hartley, J. L., Jones, G. E. (1997). Process oriented supplier development: building the capability for change. Journal of Supply Chain Management, 33(2), 24-29.

Robert, 2004 - Robert, C. P. (2004). Monte carlo methods. John Wiley \& Sons, Ltd.

Rubinstein, Kroese, 2016 - Rubinstein, R. Y., Kroese, D. P. (2016). Simulation and the Monte Carlo method, Vol. 10. John Wiley \& Sons.

Shtub et al., 1994 - Shtub, A., Bard, J.F., \& Globerson, S. (1994). Project Management Engineering, Technology and Implementation, 1 (1), Chapter 7, Project Scheduling. Prentice Hall, Inc., New Jersey.

Stark, Mayer, 1983 - Stark, R.M., Mayer, Jr., R.H. (1983). Quantitative Construction Management, Uses of Linear Optimazion, 1 (1), Chapter 8, Critical Path Method. John Wiley \& Sons, Inc., New York

Taha, 1997 - Taha, H.A. (1997). Operating Research, an introduction, Simulation Modeling. Prentice Hall, Inc., New Jersey.

Wahyu, 2008 - Wahyu, W.W. (2008). Analisis Manajemen Kuantitatif dengan Win QSB Versi 2.o, UPP STIM YKPN, Yogyakarta.

Wysocki et al., 1995 - Wysocki, R.K., Beck, Jr., R., Crane, D.B. (1995). Effective Project Management, How to Plant, Management and Deliver Project on Time and Within Budget, Estimate Activity Duration. Jhon Wiley \& Sons, Inc., New York. 